\title{
Exploration of larvicidal activity of Vernonia anthelmintica (L.) wild seed crude extracts in different solvents against malaria (Anopheles stephensi) and dengue (Aedes aegypti) vectors
}

Alina Hellert ${ }^{1,2^{*}}$, Gaurav Sharma ${ }^{2}$, Kaushal Kumar ${ }^{3}$, Veena Agrawal ${ }^{2}$

From Challenges in malaria research

Basel, Switzerland. 10-12 October 2012

\section{Background}

A large part of the population in the world is affected by one or more vector-borne diseases. The most effective way to prevent such diseases is to control the vectors [1]. Plant based insecticides are one of the best alternatives for the hazardous chemicals [2]. Leaves and fruits of Vernonia anthelmintica have been reported to have larvicidal properties against malaria vector [3]. In this study the larvicidal activity of the seeds of $V$. anthelmintica has been investigated for the first time.

\section{Materials and methods}

In this study, larvicidal activity of crude ethanol, hexane, acetone chloroform and methanol extracts of the seeds of
$V$. anthelmintica were tested against late Ill/early IV stages larvae of malaria (Anopheles Stephensi (Liston)) and dengue (Aedes aegypti (Linnaeus)) vectors [4], [5].

\section{Results}

All tested extracts showed strong larvicidal activity against the both vectors. The most effective extract against malaria vector was ethanol followed by chloroform and methanol extracts (LC50 1.95, 3.535 and 3.974 ppm; LC90 $10.49,18.325$ and $15.979 \mathrm{ppm})$. Whereas in case of dengue vector chloroform was most effective (LC50 2.76 and LC90 14.01) followed by methanol and ethanol extracts LC50 3.395 and 3.461 ppm (LC90 12.95 and 12.804 ppm) (Table 1 and 2).

Table 1 Larvicidal activity of different extracts of V.anthelmintica seeds against Late III/Early VI instar larvae of A. stephensi. No mortality was observed in the controls

\begin{tabular}{|c|c|c|c|c|c|}
\hline Solvent used for extraction & Concentration of crude extract (ppm) & Mortality (\%) & $\mathrm{LC}_{50}(\mathrm{ppm})(\mathrm{LCL}-\mathrm{UCL})$ & $\mathrm{LC}_{90}(\mathrm{ppm})(\mathrm{LCL}-\mathrm{UCL})$ & $x^{2 a}$ \\
\hline \multirow[t]{6}{*}{ Ethanol } & 50 & 100 & 1.945 & 10.492 & 5.220 \\
\hline & 25 & 99 & $(1.488-2.392)$ & $(8.479-13.837)$ & \\
\hline & 12.5 & 92 & & & \\
\hline & 6.25 & 75 & & & \\
\hline & 3.13 & 63 & & & \\
\hline & 1.56 & 48 & & & \\
\hline \multirow[t]{4}{*}{ Hexane } & 50 & 72 & 22.452 & 147.764 & 2.725 \\
\hline & 25 & 48 & $(18.692-27.831)$ & $(100.792-248.774)$ & \\
\hline & 12.5 & 36 & & & \\
\hline & 6.25 & 23 & & & \\
\hline
\end{tabular}

PPlantphysiology Department, University of Bayreuth, Bayreuth, 95440,

Germany

Full list of author information is available at the end of the article

(c) 2012 Hellert et al; licensee BioMed Central Ltd. This is an Open Access article distributed under the terms of the Creative Commons 
Table 1 Larvicidal activity of different extracts of V.anthelmintica seeds against Late III/Early VI instar larvae of A. stephensi. No mortality was observed in the controls (Continued)

\begin{tabular}{|c|c|c|c|c|c|}
\hline & 3.13 & 9 & & & \\
\hline & 1.56 & 2 & & & \\
\hline \multirow[t]{6}{*}{ Acetone } & 50 & 83 & 9.124 & 74.713 & 2.231 \\
\hline & 25 & 72 & $(7.606-10.957)$ & $(53.036-118.306)$ & \\
\hline & 12.5 & 62 & & & \\
\hline & 6.25 & 41 & & & \\
\hline & 3.13 & 28 & & & \\
\hline & 1.56 & 11 & & & \\
\hline \multirow[t]{6}{*}{ Chloroform } & 50 & 100 & 3.535 & 18.324 & $14.713^{* *}$ \\
\hline & 25 & 98 & $(1.880-5.401)$ & $(10.974-52.048)$ & \\
\hline & 12.5 & 79 & & & \\
\hline & 6.25 & 57 & & & \\
\hline & 3.13 & 45 & & & \\
\hline & 1.56 & 34 & & & \\
\hline \multirow[t]{6}{*}{ Methanol } & 50 & 100 & 3.974 & 15.979 & 8.367 \\
\hline & 25 & 97 & $(3.413-4.567)$ & $(13.198-20.310)$ & \\
\hline & 12.5 & 87 & & & \\
\hline & 6.25 & 56 & & & \\
\hline & 3.13 & 40 & & & \\
\hline & 1.56 & 25 & & & \\
\hline
\end{tabular}

$\mathrm{LC}_{50}$ Lethal concentration that kills $50 \%$ of exposed larvae; $\mathrm{LC} 90$ Lethal concentration that kills $90 \%$ of exposed larvae; LCL Lower confidence limits; UCL Upper confidence limits; $\chi^{2}$ Chi-square; ${ }^{* *}$ Significant at $P<0.01 ;{ }^{\text {a }}$ degree of freedom 4

Table 2 Larvicidal activity of different extracts of V.anthelmintica seeds against Late III/Early VI instar larvae of A. aegypti. No mortality was observed in the control

\begin{tabular}{|c|c|c|c|c|c|}
\hline Solvent used for extraction & Concentration of crude extract (ppm) & Mortality (\%) & $\mathrm{LC}_{50}(\mathrm{ppm})(\mathrm{LCL}-\mathrm{UCL})$ & $\mathrm{LC}_{90}(\mathrm{ppm})(\mathrm{LCL}-\mathrm{UCL})$ & $x^{2 a}$ \\
\hline \multirow[t]{6}{*}{ Ethanol } & 50 & 100 & 3.461 & 12.804 & $15.230^{* *}$ \\
\hline & 25 & 99 & $(2.088-5.012)$ & $(8.267-30.435)$ & \\
\hline & 12.5 & 94 & & & \\
\hline & 6.25 & 59 & & & \\
\hline & 3.13 & 43 & & & \\
\hline & 1.56 & 29 & & & \\
\hline \multirow[t]{6}{*}{ Hexane } & 50 & 83 & 14.503 & 105.282 & 5.062 \\
\hline & 25 & 61 & $(12.174-17.563)$ & $(73.710-169.855)$ & \\
\hline & 12.5 & 40 & & & \\
\hline & 6.25 & 30 & & & \\
\hline & 3.13 & 21 & & & \\
\hline & 1.56 & 6 & & & \\
\hline \multirow[t]{6}{*}{ Acetone } & 50 & 93 & 5.563 & 47.350 & 1.837 \\
\hline & 25 & 80 & $(4.537-6.699)$ & $(34.556-72.194)$ & \\
\hline & 12.5 & 66 & & & \\
\hline & 6.25 & 51 & & & \\
\hline & 3.13 & 40 & & & \\
\hline & 1.56 & 22 & & & \\
\hline \multirow[t]{6}{*}{ Chloroform } & 50 & 99 & 2.761 & 14.009 & 3.024 \\
\hline & 25 & 98 & $(2.244-3.285)$ & $(11.338-18.379)$ & \\
\hline & 12.5 & 88 & & & \\
\hline & 6.25 & 69 & & & \\
\hline & 3.13 & 53 & & & \\
\hline & 1.56 & 36 & & & \\
\hline
\end{tabular}


Table 2 Larvicidal activity of different extracts of V.anthelmintica seeds against Late III/Early VI instar larvae of A. aegypti. No mortality was observed in the control (Continued)

\begin{tabular}{|c|c|c|c|c|c|}
\hline \multirow[t]{6}{*}{ Methanol } & 50 & 100 & 3.393 & 12.945 & $9.720^{*}$ \\
\hline & 25 & 100 & $(2.301-4.584)$ & $(8.950-24.277)$ & \\
\hline & 12.5 & 89 & & & \\
\hline & 6.25 & 65 & & & \\
\hline & 3.13 & 42 & & & \\
\hline & 1.56 & 30 & & & \\
\hline
\end{tabular}

$\mathrm{LC}_{50}$ Lethal concentration that kills $50 \%$ of exposed larvae; $\mathrm{LC}_{90}$ Lethal concentration that kills $90 \%$ of exposed larvae; LCL Lower confidence limits; UCL Upper confidence limits; $\chi^{2}$ Chi-square; ;ignificant at $P<0.05$;** Significant at $P<0.01$; ${ }^{\text {a }}$ degree of freedom 4

\section{Conclusion}

This is the first report of cent percent mortality against the vectors of malaria and dengue using minimal doses of the seed extracts of $V$. anthelmintica. Further work for the isolation and characterization of larvicidal compounds is in progress.

\section{Acknowledgements}

The authors are grateful to the Indian Council of Medical Research (ICMR), New Delhi, India for providing financial assistance in the form of research project for the present investigation. Authors are also thankful to University of Delhi as well as Centre of Medical Entomology \& Vector Management, National Centre for Disease Control, Delhi, India for providing experimental support. Alina Hellert is grateful and deeply indebted to Prof. Veena Agrawal for the opportunity to do this research work in her laboratory and to all the members of her research group for their support and assistance.

\section{Author details}

'Plantphysiology Department, University of Bayreuth, Bayreuth, 95440, Germany. ${ }^{2}$ Department of Botany, University of Delhi, Delhi, 110007, India. ${ }^{3}$ Centre of Medical Entomology \& Vector Management, National Centre for Disease Control, Delhi, 110054, India.

Published: 15 October 2012

\section{References}

1. Kovendan K, Murugan K, Panneerselvam C, Kumar PM, Amerasan D, Subramaniam J, Vincent S, Barnard DR: Laboratory and field evaluation of medicinal plant extracts against filarial vector, Culex quinquefasciatus Say (Diptera: Culicidae). Parasitol Res 2012, 110:2105-2115.

2. Sharaby A, Montasser SA, Shamseldean MM, Mahmoud YA, Ibrahim SA: Plant Extracts as Alternative Botanical Insecticides for Control the Grasshopper Heteracris littoralis Ramb. (Orthoptera: Acrididae) with Reference to Histological Changes on the Reproductive System. J Basic App/ Sci Res 2011, 1(9):1031-1038.

3. Srivastava A, Bartarya R, Tonk S, Srivastava SS, Kumari M: Larvicidal activity of an indigenous plant, Centratherum anthelminticum. J Environ Biol 2008, 29(5):669-672.

4. Finney DJ: Probit analysis. Cambridge University Press, London; 1979, 68-72.

5. World Health Organization: Guidelines for laboratory and field testing of mosquito larvicides. Communicable disease control, prevention and eradication, WHO pesticide evaluation scheme. WHO Geneva, WHO/CDS/ WHOPES/GCDPP/1.3.2005.

doi:10.1186/1475-2875-11-S1-P46

Cite this article as: Hellert et al:: Exploration of larvicidal activity of Vernonia anthelmintica (L.) wild seed crude extracts in different solvents against malaria (Anopheles stephensi) and dengue (Aedes aegypti) vectors. Malaria Journal 2012 11(Suppl 1):P46.

\section{Submit your next manuscript to BioMed Central} and take full advantage of:

- Convenient online submission

- Thorough peer review

- No space constraints or color figure charges

- Immediate publication on acceptance

- Inclusion in PubMed, CAS, Scopus and Google Scholar

- Research which is freely available for redistribution 